
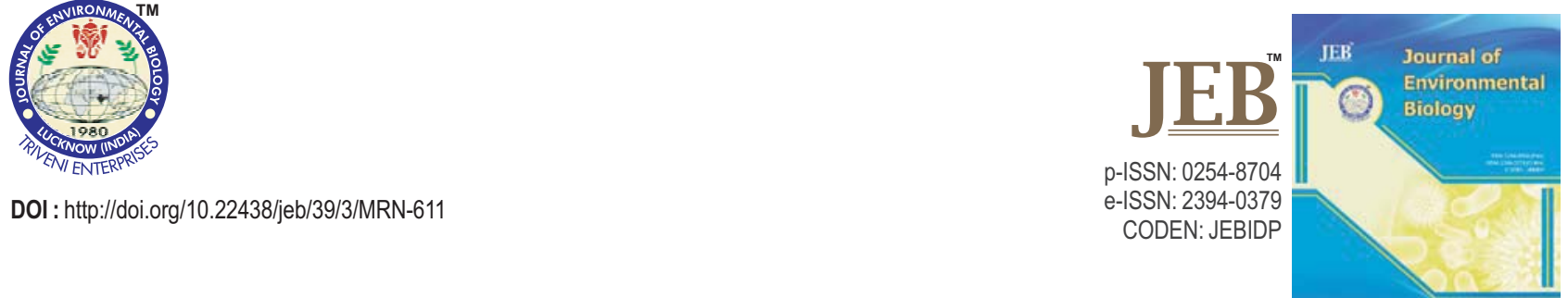

\title{
Quantitative and qualitative analysis of non-timber forest product after change in National Park Designation of Parah Forest in Thailand
}

Authors Info

\section{A. Charoensuk, M. Jaroensutasinee* and K. Jaroensutasinee}

Centre of Excellence for Ecoinformatics, School of Science, Walailak University, Nakhon $\mathrm{Si}$ Thammarat, 80161, Thailand

*Corresponding Author Email : mullica.jn@gmail.com

Key words Khao Nan National Park NTFP utilization Parah forest Socio-economics

Publication Info Paper received :08.03.2017 Revised received : 22.06 .2017 Re-revised received : 25.07 .2017 Accepted : 28.09.2017

\begin{abstract}
Aim: Non-timber forest products (NTFPs) are an important aspect of forests and forest use in many parts of the world. The present study aims at examining how local communities have changed their ways of NTFP utilization in the Parah forest after Khao Nan National Park was designated as a national park in the year 2009.

Methodology: A questionnaire survey was conducted using 150 randomly selected households from four villages bordering the Parah forest, Khao Nan National Park. The questionnaires were divided into two categories: socio-economics and NTFP utilization. The socio-economics of the interviewees were composed of gender, age group, marital status, education level, number of members/household, principle occupation and level of income. Income was categorized into three income categories, which ranged from poor (<334 \$/month), moderate (334-500 \$/month) and rich (>500 \$/month), based on the Thailand minimum daily wage. NTFP utilization composed of type of NTFP, harvested quantity and harvesting frequency.
\end{abstract}

Results: NTFPs from the Parah forest were used by $74.67 \%$ of villagers. No differences in the amount of all NTFPs obtained in 2007 and 2015 were found. However, the price of NTFPs has increased over the years, and so the value of NTFPs in the Parah forest in 2015 reached 2,773.36 US Dollars/household, which was much higher than that reported in 2007. The frequency of the NTFPs that were harvested by villagers, ranked from highest to lowest, were as follows: Parah seeds, honey, stink bean fruits (Parkia speciosa), fruits of Archidendron spp., termite mushrooms (Termitomyces spp.), fruits of Parkia javanica, medicinal plants, jiringa fruits (Archidendron jiringa), fruits of Sandoricum koetjape and bamboo shoots. The harvesting quantity of NTFPs did not change after Khao Nan National Park was designated as a National Park in the year 2009.

Interpretation: The existence of a variety of Parah NTFPs are of great importance to the villagers; therefore future planning is needed for conservation and sustainable utilization.

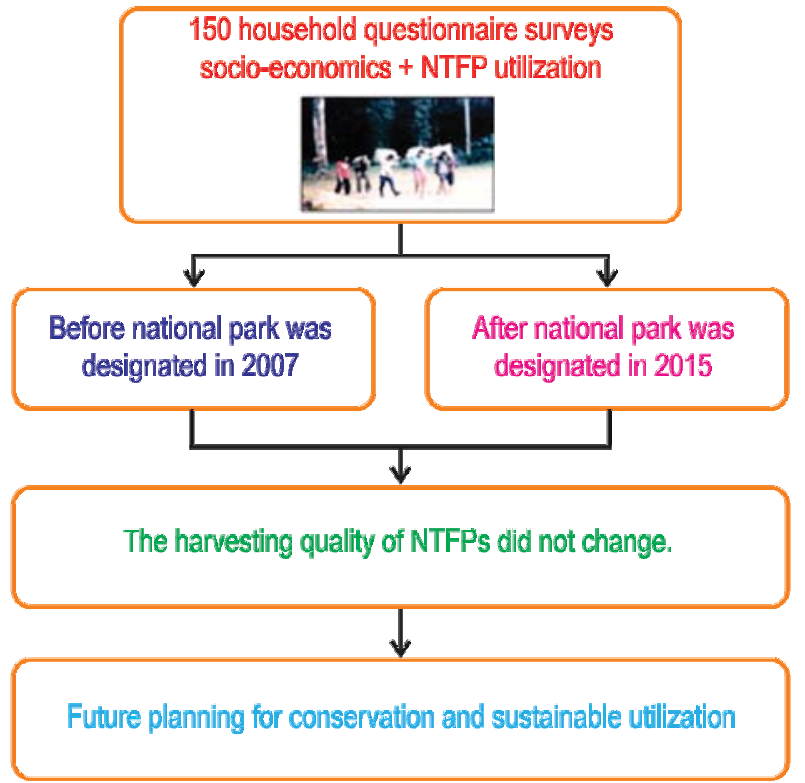




\section{Introduction}

More than 800 million people worldwide live in or near tropical forests and savannas, and rely on these ecosystems for fuel, food and income (Chomitz et al., 2007). Non-timber forest products (NTFPs) contribute significantly in maintaining livelihoods in rural Africa, Asia, and elsewhere in developing countries (Quang and Anh, 2006; Cocks et al., 2008; Wan Razali, 2012; Moupela et al., 2014). Population growth, rising per capita demand, and the development process are increasing pressure on the natural environment, requiring policy-makers to make choices about trade-offs between ecosystem conservation and economic development (Adams et al., 2004; Cheung and Sumaila, 2008; Adekunle et al., 2013). A key consideration in such decisions is how the costs and benefits of policy options are distributed across different stake holders (Schaafsma et al., 2012).

In the tropics, NTFPs are an important source of livelihood for rural communities, particularly for their food, medicines and raw materials for house construction, as well as firewood consumption (Toksoy et al., 2010; Wollenberg, 2000). Community dependence on forest resources for diverse needs has high implications for the long term management of forests. Sustainable extraction of NTFPs is considered the best feasible strategy for forest conservation in biodiversity rich areas (Saha and Sundriyal, 2012). Community attitude towards forest resources varies, depending on the distance of forest, availability of resources and access status (Sundriyal et al., 2004; Hoang et al., 2011). The organized harvesting of NTFPs can lead to sustainable development by increasing income in rural communities and by enhancing the value of forest resources, thereby providing an incentive for conservation (Hegde et al., 2017). A formal and systematic approach for uplifting of the NTFP sector could satisfactorily meet the goal of rural development and conservation of valuable natural resources. The main stakeholders in NTFP collection and trade are identified as rural collectors, traders, politicians, governmental staff, and conservation and development oriented institutions (Larsen et al., 2000).

Villagers have harvested Parah seeds and other NTFPs of the Parah forest in Khao Nan National Park, Southern Thailand, for many decades, but we know comparatively little about the quantities or the values of their utilization. Timber, poles, firewood and bush meat are prohibited in Khao Nan National Park. Forest resources available to villagers in the Parah forest are limited to NTFPs (e.g.,Parah seeds, honey, stink bean fruits (Parkia speciosa), fruits of Archidendron spp., termite mushrooms (Termitomyces spp.), fruits of Parkia javanica, medicinal plants, jiringa fruits (Archidendron jiringa), fruits of Sandoricum koetjape and bamboo shoots). Parah (Elateriospermum tapos Blume (Family Euphorbiaceae)) is the only species of the homotypic genus native to Peninsular Malaysia, Thailand, Borneo and
Sumatra. Parah trees are found in the Jengka national forest in Malaysia (Osada et al., 2003), the Belalong forest in Brunei (Cranbrook and Edwards, 1994), and Khao Nan National Park in Thailand (Chumkiew et al., 2007; Charoensuk et al., 2012). Parah trees can be found at altitudes of up to $600 \mathrm{~m}$ above sea level (Van Sam and Van Welzen, 2004). This species is abundant in the very friable, relatively nutrient-rich soil of the Sega neat series, with lower soil-water content, at least in the dry period (Ho et al., 1987). This study examined how local communities have changed their ways of utilizing NTFPs from the Parah forest after it was designated as Khao Nan National Park in the year 2009. The findings of this study would help in gaining a better understanding of Parah conservation planning to enable more sustainable utilization.

\section{Materials and Methods}

Study area : There are five main Parah clusters in Khao Nan National Park, Thailand. The largest Parah cluster is in Ban Tubnamtao, Krungching sub-district, Nakhon Si Thammarat province (Fig. 1).

Data collection: Research questions were investigated within a mixed method framework, which used different tools and approaches for collecting quantitative and qualitative data from field respondents in Krungching sub-district during the period of July to August, 2015. Data were collected from four villages in Krungching sub-district: Ban Paklong, Ban Huaytong, Ban Tubnamtao and Ban Huayhaeng. Quantitative data were collected through structured survey questionnaires, and qualitative data were collected through interviews, village meetings, and personal field observations. A total of 150 households were randomly selected from four villages in Krungching sub-district. The randomly drawn sample size was $30 \%$ of the total number of households in each village.

The questionnaires were divided into two categories: Socio-economics and NTFP utilization. The socio-economics of interviewees were composed of gender, age group, marital status, education level, number of members/household, principle occupation and level of income. We categorized income into three income categories, which ranged from poor ( $<334 \$$ per month) moderate (334-500 \$ per month), and rich (>500 \$ per month), based on the Thailand minimum daily wage. NTFP utilization was composed of type of NTFPs, harvested quantity and harvesting frequency.

Data analysis : Descriptive analysis was used to determine the overviews of economics, social aspects and forest resources of local people and communities near the Parah forest. The $t$-tests were used to test the differences between harvesting frequency/harvested households between 2007 and 2015, total NTFP differences between 2007 and 2015, and NTFP values with prices based on those from 2007 and 2015. Non-parametric tests were used where normality or other assumptions of parametric 
tests were not met. The Kruskal-Wallis test was used to test the differences between household income categories and the mean NTFP income. All significance tests were two-tailed. The total quantity and value use of NTFPs in the household and for sale were compared between 2007 and 2015 (i.e., before and after Khao Nan National Park being designated).

\section{Results and Discussion}

There were $74.67 \%$ villagers who harvested NTFPs from the Parah forest in 2015, which was lower than in 2007 (i.e., $85.32 \%$ ). The majority of villagers had completed elementary education. The education level did not differ between 2007 and 2015. The majority of villagers had 4-6 members per household. The number of members per household did not differ between 2007 and 2015. The majority of villagers had a low income in 2007, but a higher income in 2015. There was some interaction between years and levels of income, but there were no differences among household income and mean NTFP income in 2015 (Table 1).

The general statuses of villagers in 2015 was not different from those of 2007. Most of them were married, had completed elementary education, had 4-6 members per household and worked in agricultural fields. The majority of villagers in 2007 fell in a low income category; on the other hand, the majority of villagers in 2015 fell into a high income category. A possible explanation for this was that these villagers earned high incomes from rubber plantations and durian orchards. There were fewer households that harvested NTFPs from the Parah forest in 2015 than in 2007. This might be because, since the Parah forest was designated as a part of Khao Nan National Park in 2009, there have been stricter rules and regulations applied.

The use value of Parah NTFPs was 2,773.36 US Dollars per household in 2015. The villagers mostly preferred to harvest Parah seeds $(64.67 \%)$, followed by honey, stink bean fruits (Parkia speciosa), fruits of Archidendron spp., termite mushrooms, fruits of Parkia javanica, medicinal plants, jiringa fruits (Archidendron jiringa), fruits of Sandoricum koetjape and bamboo shoots, respectively. In 2015, villagers harvested Parah seeds more frequently, but harvested fruits of Sandoricum koetjape and Parkia javanica less frequently, per harvested household than in 2007. In 2015, villagers used the Parah forest as a recreation area less frequently than in 2007 (Table 2).

The total NTFPs harvested per household did not differ between 2007 and 2015 (Table 3). There were no differences among household income and mean NTFP income (Table 1).

In 2015, Parah seeds and fruits of Sandoricum koetjape had a higher NTFP value per harvested household than in 2007. There were no differences in NTFP value per harvested household in honey, fruits of Archidendron spp., stink bean fruits, medicinal plants, termite mushrooms, fruits of Parkia javanica, jiringa fruits or bamboo shoots (Table 4).

For centuries, NTFPs have played essential roles in the livelihoods of rural people inhabiting tropical rainforest areas by providing them with subsistence and households with cash incomes (Moupela et al., 2014). Our results showed that most NTFPs were sold for cash income. Villagers ranked the three most important NTFPs for sale as being fruits of Parkia javanica, honey and jiringa fruits. However, few households received incomes from fruits of Parkia javanica, as only a few Parkia trees are present in the area. Most households received incomes from Parah seeds due to direct connections with traders and middlemen. Medicinal plants, fruits of Sandoricum koetjape and bamboo shoots were extensively being used for subsistence, and contribute little in terms of income. This study clearly revealed that NTFPs were important for households and communities, and thus play vital roles in local livelihoods.

According to our observations, villagers did not depend on NTFPs for their main source of income. Income data analysis show that NTFP income did not increase with increased household income level. This suggests that even though a household becomes richer, they do not get more income from NTFPs for subsistence and cash. Therefore, NTFPs are not a major contribution to total household income. Many tropical forests remain an important source of firewood and charcoal, and many European countries see the importance of forests as a source of sustainable energy (Innes, 2013; Vincent, 2015). This is not the case here because timber, poles and firewood collection

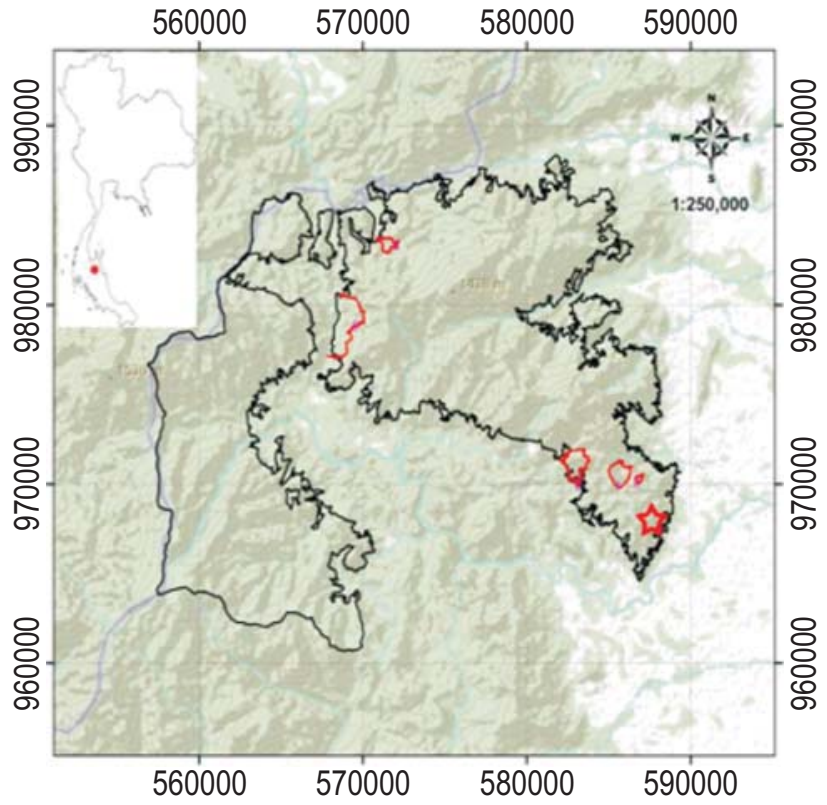

Fig. 1 : Map of Khao Nan National Park, Southern Thailand. Black line represents Khao Nan National Park boundary; red star represents park Headquarters and red line represents locations of Parah forests 
Table 1: General status of sample households $\left({ }^{*} P<0.05,{ }^{* *} P<0.001\right)$. Age group were $<30,31-40,41-50,51-60$ and $>60$. Marital status were single (S), married $(M)$, and divorced (D). Education level were elementary $(E)$, Junior high school $(J)$ and higher $(H)$. Occupation were employee $(E)$, Agriculturist (A) and (O). Monthly and NTFP income were low (L), medium (M) and high (H) incomes)

\begin{tabular}{|c|c|c|c|c|c|c|c|}
\hline \multirow[t]{2}{*}{ General status } & \multicolumn{3}{|c|}{ Households in 2007 (N=252) } & \multicolumn{3}{|c|}{ Households in 2015 ( $N=150)$} & \multirow[t]{2}{*}{ test } \\
\hline & $(\%)$ & Households & test & $(\%)$ & Households & test & \\
\hline Gender & & & & & & & \\
\hline $\begin{array}{l}\text { M:F } \\
\text { Age group (years) }\end{array}$ & $64: 35$ & $162: 90$ & $\chi_{1}^{2}=20.571^{* *}$ & $40: 60$ & $60: 90$ & $\chi_{1}^{2}=6^{*}$ & $\chi_{1}^{2}=22.428^{\star *}$ \\
\hline $\begin{array}{l}<30: 40: 50: 60:>60 \\
\text { Marital status }\end{array}$ & $11: 33: 33: 17: 6$ & $27: 82: 82: 44: 17$ & $\chi_{5}^{2}=135.667^{* *}$ & $13: 29: 30: 22: 6$ & $20: 43: 45: 33: 9$ & $\chi_{5}^{2}=67.120^{* *}$ & $\chi_{5}^{2}=3.364$ \\
\hline $\begin{array}{l}\text { S:M:D } \\
\text { Education level }\end{array}$ & $9: 91: 0$ & $22: 229: 1$ & $\chi_{2}^{2}=378.071^{* *}$ & $6: 91: 3$ & $9: 137: 4$ & $\chi_{2}^{2}=227.320^{\star *}$ & $\chi_{2}^{2}=4.806$ \\
\hline $\begin{array}{l}\text { E:J:H } \\
\text { Members/household }\end{array}$ & $73: 15: 12$ & $185: 38: 29$ & $\chi_{2}^{2}=182.643^{* *}$ & $65: 17: 18$ & $97: 26: 27$ & $\chi_{2}^{2}=66.280^{* *}$ & $\chi_{2}^{2}=4.170$ \\
\hline $\begin{array}{l}1-3: 4-6: 7-9 \\
\text { Occupation }\end{array}$ & $29: 69: 3$ & $72: 173: 7$ & $\chi_{2}^{2}=166.595^{\star *}$ & $40: 57: 3$ & $59: 86: 5$ & $\chi_{2}^{2}=68.040^{\star *}$ & $\chi_{2}^{2}=5.309$ \\
\hline $\begin{array}{l}\text { E:A:O } \\
\text { Monthly income (\$) }\end{array}$ & $2: 98: 1$ & $3: 247: 2$ & $\chi_{3}^{2}=716.571^{* *}$ & $7: 86: 7$ & $11: 129: 10$ & $\chi_{3}^{2}=298.533^{\star *}$ & $\chi_{3}^{2}=22.683^{* *}$ \\
\hline $\begin{array}{l}\text { L:M:H } \\
\text { NTFP income(\$) }\end{array}$ & $60: 28: 12$ & $151: 71: 30$ & $\chi_{2}^{2}=90.167^{* *}$ & $26: 35: 39$ & $39: 52: 59$ & $\chi_{2}^{2}=4.120$ & $\chi_{2}^{2}=56.139^{* *}$ \\
\hline L:M:H & & & & & $742: 471: 479$ & $\mathrm{H}_{2}=3.359$ & \\
\hline
\end{tabular}

Table 2 : Household harvested NTFPs and harvesting frequency/harvested households at Parah forest in 2007 and 2015. $t$-tests for harvesting frequency/harvested households between 2007 and $2015\left({ }^{*} P<0.05,{ }^{* *} P<0.01\right)$

\begin{tabular}{|c|c|c|c|c|c|}
\hline \multirow[t]{2}{*}{ Types of NTFPs } & \multicolumn{2}{|c|}{ Household harvested NTFPs (\%) } & \multicolumn{2}{|c|}{ Harvesting frequency/harvested households } & \multirow[t]{2}{*}{$t$-test } \\
\hline & 2007 & 2015 & 2007 & 2015 & \\
\hline Parah seeds & 81.35 & 64.67 & 10.19 & 13.55 & $t_{96=} 2.076^{*}$ \\
\hline Fruits of Sandoricum koetjape & 5.16 & 2.67 & 11.62 & 3.00 & $t_{3}=-21.115^{\star *}$ \\
\hline Fruits of Parkia javanica & 4.76 & 11.33 & 24.67 & 7.41 & $t_{16}=-7.906^{* *}$ \\
\hline Honey & 17.46 & 21.33 & 4.45 & 4.66 & $t_{31}=0.160$ \\
\hline Fruits of Archidendron spp. & 16.67 & 16.67 & 4.12 & 5.84 & $t_{24}=1.038$ \\
\hline Stink bean fruits & 9.13 & 19.33 & 6.91 & 8.14 & $t_{28}=0.654$ \\
\hline Medicinal plants & 7.54 & 8.67 & 3.16 & 3.31 & $t_{12}=0.102$ \\
\hline Termite mushroom & 5.95 & 11.33 & 1.53 & 2.65 & $t_{16}=1.507$ \\
\hline Jiringa fruits (Archidendron jiringa) & 3.57 & 6.67 & 3.78 & 5.70 & $t_{9}=0.677$ \\
\hline Bamboo shoots & 0.04 & 1.33 & 2.00 & 2.00 & - \\
\hline Recreation area & 24.60 & 34.00 & 22.85 & 5.25 & $t_{48}=-8.238^{* *}$ \\
\hline Natural study & 4.37 & 18.67 & 4.27 & 6.89 & $t_{28}=0.683$ \\
\hline
\end{tabular}

have been prohibited in this area for several decades. Villagers from this area have enough income from rubber plantations and durian orchards to fulfil their social functions. In contrast, many studies in the tropics reported that poor households depended on NTFPs more than richer households did (De Beer and McDermott, 1996; Pimentel et al., 1997; Arnold and Ruiz-Pérez, 2001; Belcher and Schreckenberg, 2007; Fox et al., 2007; Fu et al., 2009; Vincent, 2015).

There were differences in the harvesting frequency of Parah seeds, fruits of Sandoricum koetjape and fruits of Parkia javanica between 2007 and 2015, but there were no differences in the harvested quantities of other Parah NTFPs. In 2015, NTFP values of Parah seeds and fruits of Sandoricum koetjape were higher than in 2007, because of increased prices (Parah seed price rate per $\mathrm{kg}$ increased from 0.45 \$ in 2007 to 1.17 \$ in 2015 and fruits of Sandoricum koetjape price rate per $\mathrm{kg}$ increased from 0.33 to $1 \$$. Parah seed price and fruits of Sandoricum koetjape price rate per $\mathrm{kg}$ were based on our survey of local market prices in year 2007 and 2015. This increase in price may be the main reason for the increase in the harvesting frequency of these seeds and fruits.

The harvesting quantity of NTFPs did not change after Khao Nan National Park was designated as a National Park in the year 2009. This could due to two possible reasons: fewer 
Table 3: Types of NTFPs, NTFPs for subsistence, cash and total NTFPs per household from Parah forest in 2007 and 2015. $t$-test for total NTFP differences between 2007 and 2015

\begin{tabular}{|c|c|c|c|c|c|c|c|}
\hline \multirow[t]{2}{*}{ Types of NTFPs } & \multicolumn{2}{|c|}{ NTFPs for subsistence } & \multicolumn{2}{|c|}{ NTFPs for sale } & \multicolumn{2}{|c|}{ Total NTFPs } & \multirow[t]{2}{*}{ t-test } \\
\hline & 2007 & 2015 & 2007 & 2015 & 2007 & 2015 & \\
\hline Parah seeds $(\mathrm{kg})$ & 19.70 & 23.90 & 273.63 & 252.00 & 293.33 & 275.90 & $t_{96}=-0.332$ \\
\hline Honey (bottles) & 7.61 & 5.81 & 19.09 & 26.25 & 26.70 & 32.06 & $t_{31}=0.525$ \\
\hline Fruits of Archidendron spp. (seeds) & 759.52 & $1,044.44$ & $3,055.95$ & $7,754.00$ & $3,815.47$ & $8,798.44$ & $t_{24}=1.172$ \\
\hline Stink bean fruits (pods) & 321.74 & 447.24 & $3,800.00$ & $3,807.93$ & $4,121.74$ & $4,255.17$ & $t_{28}=0.087$ \\
\hline Medicinal plants (clumps) & 1.68 & 3.00 & - & 1.23 & 1.68 & 4.23 & $t_{12}=1.732$ \\
\hline Termite mushrooms (stems) & 29.00 & 67.65 & 37.33 & 67.65 & 66.33 & 135.29 & $t_{16}=1.204$ \\
\hline Fruits of Sandoricum koetjape (kg) & 4.31 & 4.00 & - & - & 4.31 & 4.00 & $t_{3}=-0.438$ \\
\hline Fruits of Parkia javanica (kg) & 0.92 & 67.47 & 156.17 & 161.71 & 157.09 & 229.18 & $t_{16}=0.415$ \\
\hline Jiringa fruits (Archidendron jiringa) (kg) & 14.56 & 137.20 & 111.89 & 244.80 & 126.44 & 382.00 & $t_{9}=0.875$ \\
\hline Bamboo shoots (kg) & 30.00 & 10.50 & - & - & 30.00 & 10.50 & $t_{1}=-4.333$ \\
\hline
\end{tabular}

Table 4: NTFP value per harvested household, compared with prices based on 2007 and $2015\left({ }^{*} P<0.05,{ }^{* *} P<0.01\right)$

\begin{tabular}{|c|c|c|c|c|c|}
\hline Types of NTFPs & NTFP value in 2007 (\$) & price based on 2007 (\$) & t-test & price based on $2015(\$)$ & t-test \\
\hline Parah seeds & 130.53 & 122.78 & $t_{96}=-0.270$ & 321.88 & $t_{96} 3.127^{* *}$ \\
\hline Fruits of Sandoricum koetjape & 1.42 & 1.32 & $t_{3}=-0.429$ & 4.00 & $t_{3}=3.649^{*}$ \\
\hline Honey & 244.84 & 293.99 & $t_{31}=0.525$ & 534.33 & $t_{31}=1.700$ \\
\hline Fruits of Archidendron spp. & 61.05 & 140.78 & $t_{24}=1.352$ & 234.63 & $t_{24}=1.591$ \\
\hline Stink bean fruits & 247.30 & 255.31 & $t_{28}=0.087$ & 283.68 & $t_{28}=0.469$ \\
\hline Medicinal plants & 8.40 & 21.15 & $t_{12}=1.732$ & 21.15 & $t_{12}=1.732$ \\
\hline Termite mushrooms & 7.36 & 15.02 & $t_{16}=1.196$ & 17.50 & $t_{16}=1.374$ \\
\hline Fruits of Parkia javanica & 480.16 & 700.51 & $t_{16}=0.416$ & 841.09 & $t_{16=}=0.566$ \\
\hline Jiringa fruits (Archidendron jiringa) & 123.28 & 372.45 & $t_{9=} 0.877$ & 508.06 & $t_{9=} 0.991$ \\
\hline Bamboo shoots & 14.10 & 4.94 & $t_{1}=-4.333$ & 7.04 & $t_{1}=-2.343$ \\
\hline Total & $1,318.45$ & $1,928.23$ & & $2,773.36$ & \\
\hline
\end{tabular}

households harvesting NTFPs and these fewer households harvested NTFPs more frequently. This would cause no change in the total quantity of NTFPs between 2007 and 2015. In future, local communities might need to organize harvesting of NTFPs in the Parah forest in order to encourage sustainable development by increasing income to rural communities and by enhancing the value of forest resources, thereby providing an incentive for conservation. Hegde et al. (2017) showed that engaging local communities in social learning for inclusive management for native fruit trees in the Central Western Ghats in India supports forest management. Participatory tools were composed of resource mapping, Four cell analysis, seasonal fruit calendar and seasonal activity.

NTFPs fulfill multiple functions in supporting human wellbeing, such as indirect household consumption, income generation and important roles in local culture and well-being. This is the first study that has investigated how local communities have changed their ways of NTFP utilization after Khao Nan National Park was designated as a National Park in the year 2009. The results of the present study clearly demonstrated that there were some changes in the local usage of the Parah forest after the year 2009. There was fewer numbers of households harvesting Parah seeds, but these villagers used the Parah forest more for their recreation activities. Surprisingly, NTFPs in the Parah forest are not used as the means of income generation by local villagers. In fact, their main source of income are from rubber plantations and durian orchards. The increasing income of rural communities would lead to sustainable conservation in biodiversity-rich areas, such as in Khao Nan National Park, Southern Thailand.

\section{Acknowledgments}

This work has been supported in part by the Walailak University Fund 10/2555, grant no. WU 58107, and the National Science and Technology Development Agency (NSTDA), and we thank them for their financial support. We also thank the Centre of Excellence for Ecoinformatics and NECTEC-WU. Finally, we thank the Khao Nan National Park staff for their invaluable assistant in the field.

\section{References}

Adekunle, V.A.J.,A.O. Olagoke and S.O. Akindele: Tree species diversity and structure of a Nigerian strict nature reserve. Trop. Ecol., 54, 275-289 (2013).

Adams, W.M., R. Aveling, D. Brockington, B. Dickson, B. Elliott, J. Hutton, 
B. Vira and W. Wolmer: Biodiversity conservation and the eradication of poverty. Science, 306, 1146-1149 (2004).

Arnold, J.E.M. and M. Ruiz-Pérez: Can non-timber forest products match tropical forest conservation and development objectives? Ecol. Econom., 39, 437-447 (2001).

Belcher, B. and K. Schreckenberg: Commercialisation of non-timber forest products: A reality check. Dev. Policy Rev., 25, 355-377 (2007).

Charoensuk, A., M. Jaroensutasine and K. Jaroensutasinee: Parah forest clusters at Khao National Park, Thailand. Walailak J. Sci. Tech., 9, 475-480 (2012).

Cheung, W.W.L. and U.R. Sumaila: Trade-offs between conservation and socio-economic objectives in managing a tropical marine ecosystem. Ecol. Econom., 66, 193-210 (2008).

Chomitz, K.M., P. Buys, G. De Luca, T.S. Thomas and S. WertzKanounnikoff: At loggerheads? agricultural expansion, poverty reduction and environment in the tropical forests. World Bank, Washington DC, USA (2007).

Chumkiew, S., W. Srisang, K. Jaroensutasinee and M. Jaroensutasinee: Phenology of the Parah tree (Elateriospermum tapos) using a GAPS Model. Int. J. Math. Phys. Eng. Sci., 2, 1-5 (2007).

Cocks, M.L., L. Bangay, C.M. Shackleton and F.K.Wiersum: 'Rich man poor man' inter-household and community factors influencing the use of wild plant resources amongst rural households in South Africa. Int. J. Sust. Dev. World,15, 198-210, (2008).

Cranbrook, E. and D.S. Edwards: Belalong, a tropical rainforest. Sun Tree Publishing, Singapore (1994).

De Beer, J.H. and M.J. McDermott: The economic value of non-timber forest products in Southeast Asia. Netherlands Committee for IUCN, Amsterdam (1996).

Fox, J., B.R. Bushley, S. Dutt and S.A. Quazi: Making conservation works: Linking livelihoods and protected areas in Bangladesh, East-West Center. USA and Nishorgo Program of Bangladesh Forest Department, Dhaka (2007).

Fu, Y., J. Chen, H. Guo, A. Chen, J. Cui and H. Hu: The role of non-timber forest products during agroecosystem shift in Xishuangbanna, Southwestern China. Forest Policy Econ.,11, 18-25 (2009).

Hegde, N., M. Elias, H.A.H. Lamers and M. Hegde: Engaging local communities in social learning for inclusive management of native fruit trees in the Central Western Ghats, India. For. Trees Livelihoods, 26, 65-83 (2017).

Ho, C.C., D.M. Newbery and M.E.D. Poore: Forest composition and inferred dynamics in Jengka forest reserve, Malaysia. J. Trop. Ecol., 3, 25-56 (1987).

Hoang, V.S., P. Baas, P.J.A. Keßler, J.W.F. Slik, H.T. Steege and N. Raes: Human and environmental influences on plant diversity and composition in Ben En National Park, Vietnam. J. Trop. For. Sci., 23, 328-337 (2011).
Innes, J.L.: What will we use the forests for? J. Trop. For. Sci., 25, 151$153(2013)$.

Larsen, H.O., C.S. Olsen and T.E. Boon: The non-timber forest policy process in Nepal: Actors, objectives and power. Forest Policy Econ., 1, 267-281 (2000).

Moupela, C., J.L. Doucet, K. Daïnou, Y. Brostaux, A. Fayolle and C. Vermeulen: Reproductive ecology of Coula edulis Baill., source of a valuable non-timber forest product.Trop. Ecol., 55, 327-338 (2014).

Osada, N., H. Takeda, H. Kawaguchi, A. Furukawa and M. Awang: Estimation of crown characters and leaf biomass from leaf litter in a Malaysian canopy species, Elateriospermum tapos (Euphorbiaceae). For. Ecol. Manage., 89, 379-386 (2003).

Pimentel, D., M. McNair, L. Buck, M. Pimentel and J. Kamil: The value of forests to world food security. $\square$ Hum. Ecol., 25, 91-120(1997).

Quang, D.V. and T.N. Anh: Commercial collection of NTFPs and households living in or near the forests: Case study in Que, Con Cuong and $\mathrm{Ma}$, Tuong Duong, Nghe An, Vietnam. Ecol. Econom., $60,65-74$ (2006).

Saha, D. and R.C. Sundriyal: Utilization of non-timber forest products in humid tropics: Implications for management and livelihood. Forest PolicyEcon., 14, 28-40 (2012).

Schaafsma, M., S. Morse-Jones, P. Posen, R.D. Swetnam, A. Balmford, I.J. Bateman, N.D. Burgess, S.A.O. Chamshama, B. Fisher, R.E. Green, A.S. Hepelwa, A. Hernándes-Sirvent, G.C. Kajembe, K. Kulindwa, J.F. Lund, L. Mbwambo, H. Meilby, Y.M. Ngaga, I. Theilade, T. Treue, V.G. Vyamana and R.K. Turner: Towards transferable functions for extraction of non-timber forest products: A case study on charcoal production in Tanzania. Ecol. Econom., 80, 48-62 (2012).

Sundriyal, M., R.C. Sundriyal and E. Sharma: Dietary use of wild plant resources in the Sikkim Himalaya, India. Econ. Bot., 58, 626-638 (2004).

Toksoy, D., S. Alkan and S. Hacisalihoglu: Usage of non-timber forest products by women in forest villages of Trabzon, Turkey. J. Env. Biol., 31, 1013-1016 (2010).

Van Sam, H. and P.C. Van Welzen: Revision of Annesijoa, Elateriospermum and the introduced species of Hevea in Malaysia (Euphorbiaceae). Blumea, 49, 425-440 (2004).

Vincent, J.R.: Tropical forests, for richer and for poorer. In: Sustainable humanity, sustainable nature: Our responsibility (Eds.: P.S. Dasgupta, V. Ramanathan and M. Sánchez Sorondo). The Pontifical Academy of Sciences, Vatican City, pp. 192-205 (2015).

Wan Razali, W.M.: Blame the forests for environmental degradation and biodiversity loss: in defence of the tropical forests. J. Trop. For. Sci., 24, 437-439 (2012).

Wollenberg, E.: Methods for estimating forest income and their challenges. Soc. Nat. Resour.,13, 777-795 (2000). 